\title{
Factors Influencing the Earning Capacity of NCBs in Bangladesh: An Evaluation
}

\author{
Taposh Kumar Neogy ${ }^{*}$, Aditi Sonia Aishi ${ }^{2}$
}

${ }^{1}$ Assistant Professor, Institute of Business Administration (IBA), Rajshahi under National University, BANGLADESH

${ }^{2}$ MSS, Department of Economics, University of Rajshahi, Rajshahi-6205, BANGLADESH

*E-mail for correspondence: neogyais@gmail.com

Received: Oct 12, 2017

Source of Support: Nil
Accepted: Feb 27, 2018

Published: Apr 20, 2017

No Conflict of Interest: Declared

\begin{abstract}
Recently, Bangladesh economy has been experiencing a rapid growth in most of the sectors of economic activities. For the attainment of higher levels of economic development, Bangladesh is trying to achieve and maintain high rates of economic growth. Economic development and the development of banking sector are closely related. The banks especially state-owned commercial banks have been playing significant role to the development process. The state-owned commercial bank makes the profit through banking business. But there are some factors those influence the profit volume of state-owned commercial banks. The objective of the study is to identify those influencing factors and examine the opinions of the respondents regarding the factors. It is also attempted to see whether there is any significant difference of opinions among the respondents regarding various influencing factors of profit volume using null hypotheses, $\chi 2$ test and ANOVA test. It is found that the identified factors include attitude of government, maintenance of privacy, proper control, efficiency of management, conflict in management, creativity and innovation and job satisfaction. The study also revealed that the respondents are unanimous regarding the various influencing factors of profit volume.
\end{abstract}

Keywords: Earning Capacity, NCBs, Bangladesh

\section{INTRODUCTION}

At present, the economy of Bangladesh has been experiencing a rapid growth in different sectors such as industrial and agricultural development, international trade; local and foreign investments in construction, and service enterprises ushered in an era of economic activities. Bank is a financial service institution that engages the work of transaction of money and keeps deposits of money and lends to others. The safety of saving is material of the economic development and bank ensures the safety of the savings to the individuals. By mobilizing and collecting the deposits of individual's saving bank accumulates funds for the economic development of the country. Commercial bank is the popular form of bank and indispensable for the economy of any country. A commercial bank is a profitseeking business firm, dealing in money and credit. Commercial banks are the most dominant financial institutions in the domain of commerce and industry. Banking sector provides facilities to rebuild the agriculture, industry as well as service sector by allowing loans, credit and advances. It creates an opportunity of lucrative jobs for its better employment structure. Government also in most cases depends on banking sector to meet its emergency requirements. Commercial banks, especially state-owned commercial banks, have been suited the most dynamic financial institutions due to assist the trade and commerce sector in Bangladesh. The development of banking sector has greatly impact on the economic development of Bangladesh. For the attainment of higher levels of economic development, developing country like Bangladesh is trying to achieve and maintain high rates of economic growth. The economic development of any country depends on some basic elements and commercial banks especially state-owned commercial banks are one of them. The commercial bank makes the profit through banking business it is true, but it is also true the institutions also provide some unavoidable services like aid in the remittances of money, assistance in export and import business, signing and payment of local and foreign bill and investment counseling for economic.

\section{Methodology OF the Study}

In this study, four state-owned commercial banks i. e., Sonali Bank Limited, Argani Bank Limited, Janata Bank Limited and Rupali Bank Limited have been selected as sample. Both primary and secondary data have been used for the study. Separate methods and techniques have been used for 
collecting both types of data. Primary data have been collected by structured questionnaire and through personal interview with the executives of the sample banks. Secondary data have been collected from published audited annual reports of sample banks and other published and unpublished documents. Moreover, the reading materials available in the internet and websites have also been used. Close-ended questionnaire have been prepared in the light of objectives. The questionnaire contains 10 questions. 100 respondents were selected which consist of 25 banks executives of each bank. Also five point Likert scale (greatly $=5$, moderately $=4$, partly $=3$, neutral $=2$ and not $=1$ ) has been used in this study for measuring the opinions of the selected respondents regarding the various influencing factors of the profit volume. Chi square test and ANOVA test have been used for testing different hypotheses for the present study. After preparing the draft questionnaire, a pilot survey has been conducted to examine the validity of the questionnaire and finally the opinions of the executives of sample banks have been evaluated. The Chronbach's Alpha test has been conducted for ensuring the reliability of collecting opinions from the selected respondents.

\section{HYPOTHESIS OF THE STUDY}

Based on the objective of the present research study the following null hypothesis has been developed and tested.

Ho1: There is no significant difference of opinions among the respondents regarding the various influencing factors of profit volume of the sample banks

\section{ANALYZING OF DATA}

An opinion survey was conducted to the respondents regarding the various influencing factors of profit volume. Some influencing factors of profit volume were identified. Those are attitude of government, maintenance of privacy, proper control, efficiency of management, conflict in management, creativity and innovation and job satisfaction. These are summarized below.

\section{Attitude of Government}

The attitude of Government affects the profit volume to a great extent. Government of any state takes decision about fiscal policy, monetary policy, export and import policies, industrial policy, regulatory measures and those affect the operation and success of the business. Regarding the attitude of government as an influencing factor of profit volume, the survey output has been summarized in the following Table 1:

Table No. 1: Table showing the opinion of the respondents regarding the attitude of government as an influencing factor of profit volume:

\begin{tabular}{|l|c|c|c|c|c|c|c|c|c|c|}
\hline & \multicolumn{7}{|c|}{ Respondent Groups } & \multicolumn{2}{c|}{} \\
\hline & \multicolumn{2}{|c|}{ BE_1 } & \multicolumn{2}{c|}{ BE_2 } & \multicolumn{2}{c|}{ BE_3 } & \multicolumn{2}{c|}{ BE_4 } & \multicolumn{2}{c|}{ Total } \\
\hline Types of Opinions & No. & $\%$ & No. & $\%$ & No. & $\%$ & No. & $\%$ & No. & $\%$ \\
\hline Greatly & 07 & 28.00 & 11 & 44.00 & 09 & 36.00 & 12 & 48.00 & 39 & 39.00 \\
\hline Moderately & 14 & 56.00 & 13 & 52.00 & 16 & 64.00 & 09 & 36.00 & 52 & 52.00 \\
\hline Partly & 03 & 12.00 & 01 & 04.00 & 00 & 00 & 02 & 08.00 & 06 & 6.00 \\
\hline Neutral & 00 & 00 & 00 & 00 & 00 & 00 & 01 & 04.00 & 01 & 1.00 \\
\hline Not & 01 & 04.00 & 00 & 00 & 00 & 00 & 01 & 04.00 & 02 & 2.00 \\
\hline Total & 25 & 100 & 25 & 100 & 25 & 100 & 25 & 100 & 100 & 100 \\
\hline
\end{tabular}

(Source: Field Survey)
From the above Table it is evident that $39.00 \%$ of the respondents think that the attitude of government greatly influences the profit volume, $52.00 \%$ of the respondents opine that it moderately influences, $6.00 \%$ of the respondents opine that it the partly influences, $2.00 \%$ of the respondents opine that attitude of government does not influence the profit volume and $1.00 \%$ was neutral. A null hypothesis, $\chi 2$ test and ANOVA test were conducted in order to see whether there is any significant difference of opinions among the respondents regarding the attitude of government as influencing factors of profit volume. Accordingly, our null hypothesis is Ho1.1: There is no significant difference of opinions among the respondents regarding the attitude of government as an influencing factor of profit volume. The result of $\chi 2$ test and ANOVA test can be tabulated as Table 1.A and Table 1.B. The value of chi-square is 11.846 which is significant at 0.458 levels. So, the null hypothesis is accepted and it is visible that the respondents think attitude of government influences the profit volume of any business. During ANOVA test, the value of $F$ is 1.106 and its significance level is 0.350 which means that there is no significant difference of opinions among the respondents regarding the attitude of management as an influencing factor of profit volume.

Table No. 1.A: Results of chi-square test regarding the attitude of government

\begin{tabular}{|l|c|c|c|}
\hline & Value & Df & Asymp. Sig. (2-sided) \\
\hline Pearson Chi-Square & 11.846 & 12 & 0.458 \\
\hline Likelihood Ratio & 13.702 & 12 & 0.320 \\
\hline Linear-by-Linear Association & 0.394 & 1 & 0.530 \\
\hline No. of Valid Cases & 100 & & \\
\hline
\end{tabular}

(Source: Field Survey)

Table No. 1.B: Results of ANOVA test regarding the attitude of government

\begin{tabular}{|l|c|c|c|c|c|}
\hline & Sum of Squares & Df & Mean Square & F & Sig. \\
\hline Between Groups & 2.03 & 3 & 0.677 & 1.106 & 0.350 \\
\hline Within Groups & 58.72 & 96 & 0.612 & & \\
\hline Total & 60.75 & 99 & & & \\
\hline
\end{tabular}

(Source: Field Survey)

Maintenance of Privacy: Another influencing factor of profit volume is maintenance of privacy because it plays important role in the success of business profit. An opinion survey was conducted on the respondents regarding the maintenance of privacy as an influencing factor of profit volume and the results are given in the following Table 2.

Table No. 2: Table showing the opinion of the respondents regarding the maintenance of privacy as an influencing factor of profit volume:

\begin{tabular}{|l|c|c|c|c|c|c|c|c|c|c|}
\hline & \multicolumn{7}{|c|}{ Respondent Groups } & \multicolumn{2}{c|}{} \\
\hline & \multicolumn{2}{|c|}{ BE_1 } & \multicolumn{2}{c|}{ BE_2 } & \multicolumn{2}{c|}{ BE_3 } & \multicolumn{2}{c|}{ BE_4 } & \multicolumn{2}{c|}{ Total } \\
\hline Types of Opinions & No. & $\%$ & No. & $\%$ & No. & $\%$ & No. & $\%$ & No. & $\%$ \\
\hline Greatly & 05 & 20.00 & 07 & 28.00 & 10 & 40.00 & 06 & 24.00 & 28 & 28.00 \\
\hline Moderately & 17 & 68.00 & 16 & 64.00 & 11 & 44.00 & 14 & 56.00 & 58 & 58.00 \\
\hline Partly & 01 & 04.00 & 00 & 00 & 02 & 08.00 & 03 & 12.00 & 06 & 06.00 \\
\hline Neutral & 00 & 00 & 01 & 04.00 & 00 & 00 & 02 & 08.00 & 03 & 03.00 \\
\hline Not & 02 & 08.00 & 01 & 04.00 & 02 & 08.00 & 00 & 00 & 05 & 05.00 \\
\hline Total & 25 & 100 & 25 & 100 & 25 & 100 & 25 & 100 & 100 & 100 \\
\hline
\end{tabular}

(Source: Field Survey) 
From the Table, it is found that $28.00 \%$ of the respondents think that the factor greatly influences, $58.00 \%$ of them think the factor moderately influences, $6.00 \%$ of them think that the factor partly influences, $5.00 \%$ of the them opine that it does not influence at all and only $3.00 \%$ of them were neutral. A null hypothesis, $\chi 2$ test and ANOVA test were conducted in order to see whether there is any significant difference of opinions among the respondents regarding the maintenance of privacy as an influencing factor of profit volume. Accordingly, our null hypothesis is Ho1.2: There is no significant difference of opinions among the respondents regarding the maintenance of privacy as an influencing factor of profit volume. The result of $\chi 2$ test and ANOVA test has been portrayed in Table 2.A and Table 2.B. The value of chi-square is 12.648 which is significant at 0.395 levels. So, the null hypothesis is accepted and it is found that the respondents think the maintenance of privacy influences the profit volume of any business. During ANOVA test, the value of $\mathrm{F}$ is 0.180 and its significance level is 0.909 which means that there is no significant difference of opinions among the respondents regarding the maintenance of privacy as an influencing factor of profit volume.

Table No.-2.A: Table showing the results of chi-square test

\begin{tabular}{|l|c|c|c|}
\hline Chi-Square Test & Value & df & Asymp. Sig (2-sided) \\
\hline Pearson Chi-Square & 12.648 & 12 & 0.395 \\
\hline Likelihood Ratio & 15.728 & 12 & 0.204 \\
\hline Linear-by-Linear Association & 0.020 & 1 & 0.889 \\
\hline N of Valid Cases & 100 & & \\
\hline
\end{tabular}

(Source: Field Survey)

Table No.-2.B: Table showing the results of ANOVA test

\begin{tabular}{|l|c|c|c|c|c|}
\hline & Sum of Squares & df & Mean Square & F & Sig. \\
\hline Between Groups & 0.51 & 3 & 0.170 & 0.180 & 0.909 \\
\hline Within Groups & 90.48 & 96 & 0.943 & & \\
\hline Total & 90.99 & 99 & & & \\
\hline
\end{tabular}

Proper Control

Control is inevitable for success and survival of business. Without proper control, the progress and success of organization is not ensured. For this reason management of any business gives concentration from the initial stage to maintain proper control because some problems may be arisen in the absent of proper control. An opinion survey of the respondents is made regarding the proper control as an influencing factor of profit volume and the results are given in the following Table 3 :

Table No. 3: Table showing the opinion of the respondents regarding the proper control as an influencing factor of profit volume:

\begin{tabular}{|l|c|c|c|c|c|c|c|c|c|c|}
\hline & \multicolumn{7}{|c|}{ Respondent Groups } & \multicolumn{2}{c|}{} \\
\hline & \multicolumn{2}{|c|}{ BE_1 } & \multicolumn{2}{c|}{ BE_2 } & \multicolumn{2}{c|}{ BE_3 } & \multicolumn{2}{c|}{ BE_4 } & \multicolumn{2}{c|}{ Total } \\
\hline Types of Opinions & No. & $\%$ & No. & $\%$ & No. & $\%$ & No. & $\%$ & No. & $\%$ \\
\hline Greatly & 17 & 68.00 & 19 & 76.00 & 20 & 80.00 & 22 & 88.00 & 78 & 78.00 \\
\hline Moderately & 08 & 32.0 & 06 & 24.00 & 04 & 16.00 & 03 & 12.00 & 21 & 21.00 \\
\hline Partly & 00 & 00 & 00 & 00 & 01 & 04.00 & 00 & 00 & 01 & 1.00 \\
\hline Neutral & 00 & 00 & 00 & 00 & 00 & 00 & 00 & 00 & 00 & 00 \\
\hline Not & 00 & 00 & 00 & 00 & 00 & 00 & 00 & 00 & 00 & 00 \\
\hline Total & 25 & 100 & 25 & 100 & 25 & 100 & 25 & 100 & 100 & 100 \\
\hline
\end{tabular}

(Source: Field Survey)

Table No. 3 shows the opinions of the respondents regarding the proper control as an influencing factor of profit volume. From the above Table it is visible that $78.00 \%$ of the respondents think that the proper control greatly influences, $21.00 \%$ of the respondents opine that moderately influences. Only $1.00 \%$ of the respondents think that proper control partly influences the profit volume of any business. A null hypothesis, $\chi 2$ test and ANOVA test were conducted in order to see whether there is any significant difference of opinions among the respondents regarding the proper control as an influencing factors of profit volume to test the null hypothesis and the null hypothesis is: Ho1.3: There is no significant difference of opinions among the respondents regarding the proper control as an influencing factor of profit volume. The result of $\chi 2$ test and ANOVA test can be tabulated as Table 3.A and Table 3.B. The value of chisquare is 6.476 which is significant at 0.372 levels. So, the null hypothesis is accepted and it is evident that the respondents think proper control influences the profit volume of any business. During ANOVA test, the value of $F$ is 0.85 and its significance level is 0.470 , which means that there is no significant difference of opinions among the respondent regarding the proper control as an influencing factor of profit volume. This result also corroborates the fact that the respondents are unanimous regarding the proper control as an influencing factor of profit volume.

Table No.3.A: Table showing the results of chi-square test

\begin{tabular}{|l|c|c|c|}
\hline & Value & df & Asymp. Sig. (2-sided) \\
\hline Pearson Chi-Square & 6.476 & 6 & 0.372 \\
\hline Likelihood Ratio & 6.250 & 6 & 0.396 \\
\hline Linear-by-Linear Association & 2.260 & 1 & 0.133 \\
\hline N of Valid Cases & 100 & & \\
\hline
\end{tabular}

(Source: Field Survey)

Table No. 3.B: Table showing the results of ANOVA test

\begin{tabular}{|l|c|c|c|c|c|}
\hline & Sum of Squares & df & Mean Square & F & Sig. \\
\hline Between Groups & 0.51 & 3 & 0.17 & 0.85 & 0.470 \\
\hline Within Groups & 19.2 & 96 & 0.2 & & \\
\hline Total & 19.71 & 99 & & & \\
\hline
\end{tabular}

(Source: Field Survey)

Efficiency of Management: Management is the process of designing and maintaining an environment in which individuals, working together in groups, efficiently accomplish selected aims. At present the business world is very much competitive. So, every business should be operated through the efficiency of management. An opinion survey of the respondents was made regarding the efficiency of management as an influencing factor of profit volume and the results are given in the following Table 4:

Table No. 4: Table showing the opinions of the respondents regarding the efficiency of management as an influencing factor of profit volume:

\begin{tabular}{|l|c|c|c|c|c|c|c|c|c|c|c|}
\hline & \multicolumn{7}{|c|}{ Respondent Groups } & \multicolumn{2}{c|}{} \\
\hline & \multicolumn{2}{|c|}{ BE_1 } & \multicolumn{2}{|c|}{ BE_2 } & \multicolumn{2}{c|}{ BE_3 } & \multicolumn{2}{c|}{ BE_4 } & \multicolumn{2}{c|}{ Total } \\
\hline Types of Opinions & No. & $\%$ & No. & $\%$ & No. & $\%$ & No. & $\%$ & No. & $\%$ \\
\hline Greatly & 16 & 64.00 & 16 & 64.00 & 22 & 88.00 & 18 & 72.00 & 72 & 72.00 \\
\hline Moderately & 08 & 32.00 & 07 & 28.00 & 03 & 12.00 & 07 & 28.00 & 25 & 25.00 \\
\hline Partly & 01 & 04.00 & 02 & 08.00 & 00 & 00 & 00 & 00 & 03 & 03.00 \\
\hline Neutral & 00 & 00 & 00 & 00 & 00 & 00 & 00 & 00 & 00 & 00 \\
\hline Not & 00 & 00 & 00 & 00 & 00 & 00 & 00 & 00 & 00 & 00 \\
\hline Total & 25 & 100 & 25 & 100 & 25 & 100 & 25 & 100 & 100 & 100 \\
\hline
\end{tabular}

(Source: Field Survey) 
Table No. 4 highlights the opinions of the respondents regarding the efficiency of management as an influencing factor of profit volume. From the above Table it is evident that $72.00 \%$ of the respondents think that the efficiency of management greatly influences, $25.00 \%$ of the respondents opine that moderately influences. Only $3.00 \%$ of the respondents opine that the partly influences. A null hypothesis, $\chi 2$ test and ANOVA test were conducted in order to see whether there is any significant difference of opinions among the respondents regarding the efficiency of management as an influencing factor of profit volume to test the null hypothesis and the null hypothesis is: Ho1.4: There is no significant difference of opinions among the respondents regarding the efficiency of management as an influencing factor of profit volume. The result of $\chi 2$ test and ANOVA test can be tabulated as Table 4.A and Table 4.B. The value of chisquare is 7.360 which is significant at 0.289 levels. So, the null hypothesis is accepted and it is apparent that the respondents think the efficiency of management influences the profit volume of any business. During ANOVA test, the value of F is 1.920 and its significance level is 0.132 , which means that there is no significant difference of opinions among the respondents regarding the efficiency of management as an influencing factor of profit volume.

Table No. 4.A: Table showing the results of chi-square test

\begin{tabular}{|l|c|c|c|}
\hline & Value & df & Asymp. Sig. (2-sided) \\
\hline Pearson Chi-Square & 7.360 & 6 & 0.289 \\
\hline Likelihood Ratio & 8.509 & 6 & 0.203 \\
\hline Linear-by-Linear Association & 2.089 & 1 & 0.148 \\
\hline N of Valid Cases & 100 & & \\
\hline
\end{tabular}

(Source: Field Survey)

Table No. 4.B: Table showing the results of ANOVA test

\begin{tabular}{|l|c|c|c|c|c|}
\hline & Sum of Squares & df & Mean Square & F & Sig. \\
\hline Between Groups & 1.55 & 3 & 0.517 & 1.920 & 0.132 \\
\hline Within Groups & 25.84 & 96 & 0.269 & & \\
\hline Total & 27.39 & 99 & & & \\
\hline
\end{tabular}

(Source: Field Survey)

\section{Conflict in Management}

Management conflict is an important influencing factor and it influences the profit volume of any business. Conflict is a serious problem in an organization and it can create confusing environment where it is impossible for employees to work together but the success of business completely depends on the group work and it is possible when existing manpower can work under conflict free environment. Due to loss of reciprocal understanding management faces detrimental conflict and which may harm in the case of success of business because the activities of different levels of management are closely related with one another. An opinion survey was made of the respondents regarding the conflict in management as an influencing factor of profit volume and the results are given in the following Table 5:

Table No. 5: Table showing the opinions of the respondents regarding the conflict in management as an influencing factor of profit volume:

\begin{tabular}{|l|c|c|c|c|c|c|c|c|c|c|}
\hline & \multicolumn{7}{|c|}{ Respondent Groups } & \multicolumn{2}{c|}{} \\
\hline & \multicolumn{2}{|c|}{ BE_1 } & \multicolumn{2}{|c|}{ BE_2 } & \multicolumn{2}{c|}{ BE_3 } & \multicolumn{2}{c|}{ BE_4 } & \multicolumn{2}{c|}{ Total } \\
\hline Types of Opinions & No. & $\%$ & No. & $\%$ & No. & $\%$ & No. & $\%$ & No. & $\%$ \\
\hline Greatly & 09 & 36.00 & 13 & 52.00 & 10 & 40.00 & 11 & 44.00 & 43 & 43.00 \\
\hline Moderately & 13 & 52.00 & 12 & 48.00 & 14 & 56.00 & 11 & 44.00 & 50 & 50.00 \\
\hline Partly & 02 & 08.00 & 00 & 00 & 01 & 04.00 & 02 & 08.00 & 05 & 05.00 \\
\hline Neutral & 00 & 00 & 00 & 00 & 00 & 00 & 00 & 00 & 00 & 00 \\
\hline Not & 01 & 04.00 & 00 & 00 & 00 & 00 & 01 & 04.00 & 02 & 02.00 \\
\hline Total & 25 & 100 & 25 & 100 & 25 & 100 & 25 & 100 & 100 & 100 \\
\hline
\end{tabular}

(Source: Field Survey)

Table No. 5 shows the opinions of the respondents regarding the conflict in management as an influencing factor of profit volume. From the above Table it is evident that $43.00 \%$ of the respondents think that the conflicts in management greatly influence, $50.00 \%$ of the respondents opine that moderately influence. $5.00 \%$ of the respondents think that partly influence and $2.00 \%$ of the respondents think that conflict in management does not influence the profit volume. A null hypothesis, $\chi 2$ test and ANOVA test were conducted in order to see whether there is any significant difference of opinions among the respondents regarding the conflict of management as an influencing factors of profit volume to test the null hypothesis and the null hypothesis is: Ho1.5: There is no significant difference of opinions among the respondents regarding the conflict in management as an influencing factor of profit volume. The result of $\chi 2$ test and ANOVA test can be tabulated as Table 5.A and Table 5.B. The value of chi-square is 5.414 , which is significant at 0.797 levels. So, the null hypothesis is accepted and it is visible that the respondents think conflict in management as an influencing factor of profit volume of any business. During ANOVA test, the value of $F$ is 1.092 and its significance level is 0.356 , which means that there is no significant difference of opinions among the respondent regarding the conflict in management as an influencing factor of profit volume.

Table No. 5.A: Table showing the results of chi-square test

\begin{tabular}{|l|c|c|c|}
\hline & Value & df & Asymp. Sig. (2-sided) \\
\hline Pearson Chi-Square & 5.414 & 9 & 0.797 \\
\hline Likelihood Ratio & 7.289 & 9 & 0.607 \\
\hline Linear-by-Linear Association & 0.014 & 1 & 0.905 \\
\hline N of Valid Cases & 100 & & \\
\hline
\end{tabular}

(Source: Field Survey)

Table No. 5.B: Table showing the results of ANOVA test

\begin{tabular}{|l|c|c|c|c|c|}
\hline & Sum of Squares & df & Mean Square & F & Sig. \\
\hline Between Groups & 1.84 & 3 & 0.613 & 1.092 & 0.356 \\
\hline Within Groups & 53.92 & 96 & 0.562 & & \\
\hline Total & 55.76 & 99 & & & \\
\hline
\end{tabular}

(Source: Field Survey)

\section{Creativity and Innovation}

An important influencing factor of profit volume is creativity and innovation. The term creativity generally refers to the ability and power to develop new ideas, is important for effective managing. Innovation is the use of these ideas (Weihrich and Koontz, 2006). Business tries to develop new products for its customer and for this reasons business functions include research and development. Proper knowledge about creativity and innovation ensures the success in future time and successful business must grow and expand. An opinion survey of the respondents was made regarding the 
creativity and innovation as an influencing factor of profit volume and the results are given in the following Table 6:

Table No. 6: Table showing the opinions of the respondents regarding the creativity and innovation as an influencing factor of profit volume:

\begin{tabular}{|l|c|c|c|c|c|c|c|c|c|c|}
\hline & \multicolumn{7}{|c|}{ Respondent Groups } & \multicolumn{2}{c|}{} \\
\hline & \multicolumn{2}{|c|}{ BE_1 } & \multicolumn{2}{c|}{ BE_2 } & \multicolumn{2}{c|}{ BE_3 } & \multicolumn{2}{c|}{ BE_4 } & \multicolumn{2}{c|}{ Total } \\
\hline Types of Opinions & No. & $\%$ & No. & $\%$ & No. & $\%$ & No. & $\%$ & No. & $\%$ \\
\hline Greatly & 14 & 56.00 & 14 & 56.00 & 17 & 68.00 & 10 & 40.00 & 55 & 55.00 \\
\hline Moderately & 10 & 40.00 & 11 & 44.00 & 06 & 24.00 & 14 & 56.00 & 41 & 41.00 \\
\hline Partly & 01 & 04.00 & 00 & 00 & 01 & 04.00 & 01 & 04.00 & 03 & 03.00 \\
\hline Neutral & 00 & 00 & 00 & 00 & 01 & 04.00 & 00 & 00 & 01 & 01.00 \\
\hline Not & 00 & 00 & 00 & 00 & 00 & 00 & 00 & 00 & 00 & 00 \\
\hline Total & 25 & 100 & 25 & 100 & 25 & 100 & 25 & 100 & 100 & 100 \\
\hline
\end{tabular}

(Source: Field Survey)

Table No. 6 shows the opinions of the respondents regarding the creativity and innovation as an influencing factor of profit volume. From the above Table it is evident that $55.00 \%$ of the respondents opine that the creativity and innovation greatly influence, $41.00 \%$ of the respondents think that moderately influence. Only $3.00 \%$ of the respondents think that the partly influences and $1.00 \%$ was neutral. A null hypothesis, $\chi 2$ test and ANOVA test were conducted in order to see whether there is any significant difference of opinions among the respondents regarding the creativity and innovation as an influencing factors of profit volume. Accordingly, our null hypothesis is: Ho1.6: There is no significant difference of opinions among the respondents regarding the creativity and innovation as an influencing factor of profit volume. The result of $\chi 2$ test and ANOVA test can be tabulated as Table 6.A and Table 6.B. The value of chi-square is 8.995 which is significant at 0.438 levels. So, the null hypothesis is accepted and it is evident that the respondents think the creativity and innovation influences the profit volume of any business. During ANOVA test, the value of $\mathrm{F}$ is 0.599 and its significance level is 0.617 , which means that there is no significant difference of opinions among the respondent regarding the creativity and innovation as an influencing factor of profit volume.

Table No. 6.A: Table showing the results of chi-square test

\begin{tabular}{|l|c|c|c|}
\hline & Value & df & Asymp. Sig. (2-sided) \\
\hline Pearson Chi-Square & 8.995 & 9 & 0.438 \\
\hline Likelihood Ratio & 9.716 & 9 & 0.374 \\
\hline Linear-by-Linear Association & 0.771 & 1 & 0.380 \\
\hline N of Valid Cases & 100 & & \\
\hline
\end{tabular}

(Source: Field Survey)

Table No. 6.B: Table showing the results of ANOVA test

\begin{tabular}{|l|c|c|c|c|c|}
\hline & Sum of Square & df & Mean Square & F & Sig. \\
\hline Between Groups & 0.68 & 3 & 0.227 & 0.599 & 0.617 \\
\hline Within Groups & 36.32 & 96 & 0.378 & & \\
\hline Total & 37 & 99 & & & \\
\hline
\end{tabular}

(Source: Field Survey)

\section{Job Satisfaction}

Job satisfaction is another important influencing factor of profit volume. Job satisfaction reduces turnover, absenteeism and grievances and increase the productivity. So, the management of business should give attention to create and maintain job satisfaction of their existing manpower. An opinion survey of the respondents regarding the job satisfaction as an influencing factor of profit volume and the results are given in the following Table 7:

Table No. 7: Table showing the opinions of the respondents regarding the job satisfaction as an influencing factor of profit volume:

\begin{tabular}{|l|c|c|c|c|c|c|c|c|c|c|}
\hline & \multicolumn{7}{|c|}{ Respondent Groups } & \multicolumn{2}{c|}{} \\
\hline & \multicolumn{2}{|c|}{ BE_1 } & \multicolumn{2}{|c|}{ BE_2 } & \multicolumn{2}{c|}{ BE_3 } & \multicolumn{2}{c|}{ BE_4 } & \multicolumn{2}{c|}{ Total } \\
\hline Types of Opinions & No. & $\%$ & No. & $\%$ & No. & $\%$ & No. & $\%$ & No. & $\%$ \\
\hline Greatly & 13 & 52.00 & 15 & 60.00 & 18 & 72.00 & 16 & 64.00 & 62 & 62.00 \\
\hline Moderately & 10 & 40.00 & 09 & 36.00 & 06 & 24.00 & 09 & 36.00 & 34 & 34.00 \\
\hline Partly & 02 & 08.00 & 01 & 04.00 & 00 & 00 & 00 & 00 & 03 & 03.00 \\
\hline Neutral & 00 & 00 & 00 & 00 & 01 & 04.00 & 00 & 00 & 01 & 01.00 \\
\hline Not & 00 & 00 & 00 & 00 & 00 & 00 & 00 & 00 & 00 & 00 \\
\hline Total & 25 & 100 & 25 & 100 & 25 & 100 & 25 & 100 & 100 & 100 \\
\hline
\end{tabular}

(Source: Field Survey)

Table No. 7 presets the opinions of the respondents regarding the job satisfaction as an influencing factor of profit volume. From the above Table it is evident that $62.00 \%$ of the respondents think that the job satisfactions greatly influence, $34.00 \%$ of the respondents opine that moderately influence. Only $3.00 \%$ of the respondents think that the partly influence and $1.00 \%$ was neutral. A null hypothesis, $\chi 2$ test and ANOVA test were conducted in order to see whether there is any significant difference of opinions among the respondents regarding the job satisfaction as an influencing factors of profit volume to test the null hypothesis and the null hypothesis is: Ho1.7: There is no significant difference of opinions among the respondents regarding the job satisfaction as an influencing factor of profit volume. The result of $\chi 2$ test and ANOVA test can be tabulated as in Table 7.A and Table 7.B. The value of chi-square is 8.564 which is significant at 0.478 levels. So, the null hypothesis is accepted and it is visible that the respondents think the job satisfaction influences the profit volume of any business. During ANOVA test, the value of $F$ is 0.598 and its significance level is 0.618 , which means that there is no significant difference of opinions among the respondents regarding the job satisfaction as an influencing factor of profit volume.

Table No. 7.A: Table showing the results of chi-square test

\begin{tabular}{|l|c|c|c|}
\hline & Value & df & Asymp. Sig. (2-sided) \\
\hline Pearson Chi-Square & 8.564 & 9 & 0.478 \\
\hline Likelihood Ratio & 9.242 & 9 & 0.415 \\
\hline Linear-by-Linear Association & 1.567 & 1 & 0.211 \\
\hline N of Valid Cases & 100 & & \\
\hline
\end{tabular}

(Source: Field Survey)

Table No. 7.B: Table showing the results of ANOVA test

\begin{tabular}{|l|c|c|c|c|c|}
\hline & Sum of Squares & df & Mean Square & F & Sig. \\
\hline Between Groups & 0.67 & 3 & 0.223 & 0.598 & 0.618 \\
\hline Within Groups & 35.84 & 96 & 0.373 & & \\
\hline Total & 36.51 & 99 & & & \\
\hline
\end{tabular}

(Source: Field Survey)

\section{TEST OF RELIABILITY}

The reliability test is used to find out the reliability of the results of the opinions of the respondents regarding the influencing factors of profit volume of any business. The Chronbach's Alpha test has been used to test reliability and the results are given in the following Table 8: 
Table No. 8: Table showing the Cronbach Alpha test results of the opinions of the respondents regarding the influencing factors of profit volume.

\begin{tabular}{|c|r|c|c|c|}
\hline No. of Items & Mean & Variance & Std. Dev. & Alpha Value \\
\hline 07 & 31.120 & 16.5107 & 4.0633 & 0.9322 \\
\hline
\end{tabular}

The Cronbach Alpha test has been conducted for the purpose of testing the reliability of results regarding the influencing factors of profit volume. The result shows that the value of Alpha is above 0.7. On the basis of the results it is evident that the results regarding the opinions of the respondents regarding the influencing factors of profit volume are reliable.

\section{CONCLUSION AND RECOMMENDATIONS}

The study analyzes the opinions of the respondents regarding the various influencing factors of profit volume to achieve the objective. As per objective of the study and testing of the hypotheses it can be concluded that the majority respondents think that the attitude of government, maintenance of privacy and conflict in management moderately influence on profit volume of business and other wise proper control, efficiency of management, creativity and innovation and job satisfaction greatly influence on profit volume. The study shows that the all null hypotheses are accepted which means that there is no significant difference of opinions among the respondents regarding the various influencing factors of profit volume. From the previous discussion it is evident that the selected respondents are unanimous regarding the various influencing factors of profit volume which means that the aforesaid factors influence the profit volume of business. Every business operates under the framework of government policies and regulations. So, the attitude of government should be cordial to the business so that the management can operate their business smoothly in favourable of earning profit. The conflict in the different level of management is harmful for the success of business. So, it is necessary to reduce the conflict so that they can work mutually. Management of the sample banks should maintain the favorable environment so that the existing manpower in the different stages can work positively and it is necessary to successfully run any business for long time. The efficiency of management is necessary for ensuring the sound management. So, every sample bank should give concentration to increase the efficiency of their existing employees through proper training about business management who are involved in the different levels of the total management. Since earning profit is the ultimate objective of any business and it is the indicator to judge the operational performance and efficiency of management, proper control should be mandatory in all level of management in case of success of any business.

\section{REFERENCES}

Ahmed AA and Dey MM. 2009. Bank Loan Officers' Perceptions Of Corporate Financial Disclosure In The Banking Sector Of Bangladesh: An Empirical Analysis, In: CIIT, ed. CIIT Proceedings 2nd CBRC. Lahore, Pakistan: COMSATS Institute of Information Technology.

Ahmed AA and Neogy TK. 2010. Forensic Accounting in Bangladesh: Emergence and Introduction, Development Compilation, 3, 71-82.

Ahmed AA. 2009. Measurement and Analysis of the Extent of Timeliness in Corporate Annual Reports of Banking Sector in Bangladesh Development Compilation, 1, 45-56.
Ahmed, A. A. A., "Compliance of Financial Disclosure in the Corporate Annual Reports of Banking Sector of Bangladesh", Unpublished Ph. D thesis, Department of Accounting and Information Systems, University of Rajshahi, Rajshahi, Bangladesh. (2010).

Alam, M. J., "Compliance with Accounting Standards in Financial Reporting of Commercial Banks in Bangladesh", unpublished Ph. D Dissertation, Institute of Bangladesh Studies, Rajshahi University, University of Rajshahi, Rajshahi, Bangladesh. (2013).

Ali, M. S., "Capacity Utilization and Profitability of Sugar Mills in Bangladesh", The Islamic University Studies, Volume 3, No. 2, December. (2000).

Ali. and Saha, "Productivity Measurement of Commercial Banks in Bangladesh", The Islamic University Studies, Part - C, Volume 3, No. 2, December. (2000).

Audited Annual Reports of the Sample State-Owned Commercial Banks in Bangladesh.

Baberhee, B., "Financial Policy and Management Accounting", the World Press Private Ltd., Calcutta.(1990).

Bangladesh Economic Review, Economic Adviser's Wing, Finance Division, Ministry of Finance, Government of the People's Republic of Bangladesh, June.(2009).

Bhuiyan, M. N. U., "Introduction to Business and Business Administration",NsSyPeC Publications, Dhaka, Bangladesh. (2010).

Brigham, E. F. and Ehrhardt, M. C, "Financial Management", Thomson, USA. (2000).

Hossain, M. S., Neogy, T. K. and Biswan, T. "the Evaluation of Growth Rate of Different Aspects of Commercial Banks in Bangladesh: An Evaluation", International Scholar Journal of Accounting and Finance, Volume-2, No. 1. (2016)

Husain, S. M., "Profitability Analysis in Mechanized Inland Water Transport of Bangladesh", the Dhaka University Studies, Part - C, Volume - 11 (2). (1990)

Kabir, M. H., "Cost Behaviour and Profitability: A Study on Some Company Sugar Mills in Bangladesh", Journal of the Institute of Bangladesh Studies, ISSN 0256-503X, Volume - XXIII. (2000).

Khan, M.Y. and Jain, P.K., "Financial Management, Prentice Hall of India, New Delhi. (2002)

Neogy, T. K. and Ahmed, A. A. A., "The Extent of Disclosure Different Components of Disclosure Index: A Study on Commercial Banks in Bangladesh", Global Disclosure of Economics and Business, Volume4, No. 2, (2015).

Neogy, T. K., "Evaluation of the Legal Framework and Accounting Standards: A Study on Mobile Telecommunication Companies in Bangladesh", ABC Journal of Advanced Research, Volume 4, No. 1. (2015).

Pandey, I. M., "Financial Management", Vikas Publishing House Pvt. Ltd., Delhi, (2007).

Rahman and Belal, "Profitability of Urea Fertilizer Sample Companies in Bangladesh: A Comparative Study", the Chittagong University Studies, Commerce, Volume 5, No. 1, (1991).

Robbins, S. P., “Organizational Behavior", Eleventh Edition, PrenticeHall of India Private Limited, New Delhi, (2005).

Weihrich, H. and Koontz, H.," Management: A Global Perspective", Eleventh Edition, McGraw-Hill Education (Asia), (2006).

$$
--0--
$$

\section{Social ScIENCE RESEARCH NETWORK 2171 Monroe Avenue, Suite 203, Rochester, NY 14618, USA http://www.ssrn.com/en/} ATTP Link: http://www.ssrn.com/link/American-Journal-Trade-Policy.html 